Original Paper http://ajol.info/index.php/ijbcs $\quad$ http://indexmedicus.afro.who.int

\title{
Comparative analysis of nutrient composition and glycaemic indices of nine sweet potatoes (Ipomoea batatas) varieties
}

\author{
Galahitiya Ralalage Nipuni Nayanathara WAIDYARATHNA ${ }^{1}$, Sagarika EKANAYAKE ${ }^{1, *}$ \\ and Anoma CHANDRASEKARA ${ }^{2}$ \\ ${ }^{1}$ Department of Biochemistry, Faculty of Medical Sciences, University of Sri Jayewardenepura, Gangodawila, \\ Nugegoda, Sri Lanka. \\ ${ }^{2}$ Department of Applied Nutrition, Faculty of Livestock Fisheries and Nutrition, Wayamba University of Sri \\ Lanka, Makandura, Gonawila, Sri Lanka. \\ *Corresponding author; E-mail: sagarikae@hotmail.com; sagarikae@sjp.ac.lk; Tel: (+94)0716875891
}

Received: 05-12-2020 Accepted: 24-4-2021 $\quad$ Published: 31-08-2021

\begin{abstract}
Sweet potatoes are one of the major tuberous roots consumed around the world. The objective of the present study was to determine the nutritional composition, glycaemic indices and glycaemic loads of selected Sri Lankan sweet potato varieties, in order to address the inadequacy of information and the controversial findings on glycaemic indices. Nutrient composition (moisture, ash, digestible carbohydrates, dietary fiber, crude protein and fat) of boiled sweet potatoes, GI and glycaemic loads (GL) of nine varieties were determined using standard methods. Digestible carbohydrate content ranged between 29-88\% on dry weight. Ash, crude protein and crude fat contents of the varieties ranged between 3.1-5.0\%, 3.0-5.9\% and 2.6-5.3\% on dry weight basis (DW) respectively. The total dietary fiber content was above $9.5 \% \mathrm{DW}$ in the studied varieties. Moisture content of boiled sweet potato tubers were $72-81 \%$ on fresh weight basis and both the GIs (86-119) and GLs (>20) were high. However, the GL reduced to medium or low when considering an actual edible portion for all the varieties except for two varieties. Sweet potatoes are a good source of highly available carbohydrates which elicit high GIs.
\end{abstract}

(C) 2021 International Formulae Group. All rights reserved.

Keywords: Sweet potatoes, proximate composition, digestible carbohydrate, glycaemic index, glycaemic load.

\section{INTRODUCTION}

Sweet potatoes (Ipomoea batatas L.), ranked as the seventh most important food crop in the World in terms of the production are one of the major tuberous roots consumed in over hundred countries around the world (Doussoh et al., 2016; Mussoline and Wilkie, 2017). Sweet potatoes belong to family
Convolvulaceae and are large, starchy and sweet tasting. Currently sweet potatoes are widely grown in many tropical, subtropical countries and in different ecological regions (FAO, 2016), as these tubers could withstand many stressful conditions under many farming conditions with low pesticides requirement. The tubers can be harvested over a long 
period of time and thus considered as a typical food security crop (Chandrasekara and Kumar, 2016).

Carbohydrate is the major macronutrient present in sweet potatoes. Low crude fat (0.02- 4\%) (Ukom et al., 2009; Oluwalana et al., 2012; Ellong et al., 2014), with wide variation of crude protein (1-20\%) (Kamal et al., 2013; Senanayake et al., 2013) and crude fiber $(0.3-15 \%)$ (Rose and Vasanthakaalam, 2011; Ellong et al., 2014) are present on dry weight basis. Sweet potato varieties with white, yellow, orange and purple flesh are rich sources of bioactive compounds and antioxidants (Djinet et al., 2014; Wang et al., 2018).

As one of the starchy roots consumed by people in different regions of the World including Sri Lanka, the knowledge on glycaemic response of sweet potato tubers, in terms of glycaemic index (GI) and glycaemic load is important. Such data on Sri Lankan sweet potatoes are not available and other reported data on glycaemic indices are contradictory. Medium glycaemic indices resulted for steamed $(63 \pm 3.6)$, baked $(64 \pm$ $4.3)$ and micro waved $(66 \pm 5.7)$ sweet potatoes (Allen et al., 2012) whereas some GI values for boiled sweet potatoes were low (Foster-Powell et al., 2002; Bahado-Singh et al., 2011) or ranged from low to high (Atkinson et al., 2008).

Even though Sri Lanka produces a variety of sweet potatoes reaching an annual production of 40,000 tons in year 2017 (FAOSTAT, 2017), data on glycaemic indices of the many varieties of sweet potatoes have not been determined. Similarly, there are limited data on nutritional composition of the boiled ready to eat sweet potato varieties available in Sri Lanka. Boiled sweet potatoes are the commonest form of preparation by many Asians. Therefore, the objective of the present study was to determine the nutritional composition of selected Sri Lankan sweet potatoes prepared by boiling, and determine the glycaemic indices and glycaemic loads in order to fulfill the lack of information for the benefit of people.

\section{MATERIALS AND METHODS}

\section{Sweet potatoes}

The nine sweet potato varieties selected for the study were Ama, Dhawala, Wariyapola White $(W W)$, Wariyapola Red (WR), Hordi Malee (HM), CARI 273, Ranabima, Gannoruwa White $(G W)$, and Makandura Purple (MP). Sweet potato samples were collected from Plant Genetic Resource Center Gannoruwa, Sri Lanka and Agricultural Research Center, Makandura, Sri Lanka.

\section{Sweet potato flour and food preparation for GI study}

Sweet potato samples were washed, hand peeled (minimal removal of peel) and trimmed to remove defective parts. The tubers were chopped into medium sized pieces and boiled as per home cooking by adding water and boiling for 10-20 minutes as required for each variety. The boiled sweet potatoes were mashed and dried in the oven at $55{ }^{\circ} \mathrm{C}$ for 3-4 days. Dried samples were milled (IKA ® A11 basic, New Zealand), sieved and stored (-20 ${ }^{\circ} \mathrm{C}$ ) in tightly closed containers until subjected to the nutrient composition analyses.

Boiled sweet potatoes for the GI study was prepared as mentioned above. Boiled sweet potato portion was served with onion sambol (50 g prepared by grinding red onion $(35 \mathrm{~g})$, pieces of dry red chilies (10 g), pepper $(2 \mathrm{~g})$ and salt $(1 \mathrm{~g})$ mixed with $(2 \mathrm{~mL})$ lime juice). Sample portion sizes of four sweet potato varieties are presented in Figure 1.

\section{Determination of nutrient composition}

Flour made from boiled sweet potatoes was used for the analyses. Moisture (AOAC, 1984), ash (AOAC, 2000), crude protein (Kjeldhal method with the conversion factor of 6.25) (AOAC, 1984), crude fat (method 
described by Croon and Guchs (1980) with modification), digestible carbohydrates (AOAC, 2005) (using enzymatic assay with Megazyme total starch assay procedure (amyloglucosidase/ $\alpha$-amylase method; KTSTA-50A/K-TSTA-100A 06/17; Megazyme, Ireland, without washing off simple sugars present in the samples) were determined. Dietary fiber contents including insoluble and soluble dietary fiber determined using the total dietary fiber assay kit (TDF 100A-1KT, SIGMA ALDRICH, USA).

\section{Determination of glycaemic response and glycaemic index}

Apparently healthy $(n=10$, age 20-30 years) volunteers with BMI in the range of $18.5-23 \mathrm{~kg} / \mathrm{m}^{2}$ and not on any medical treatment were selected for the GI and GL determination study. As the portion size of a $50 \mathrm{~g}$ available carbohydrate portion was too large to be consumed, the test meal of boiled sweet potatoes containing an available $25 \mathrm{~g}$ carbohydrate portion was used in the GI study. Glycaemic index was determined using WHO standard procedure (FAO/WHO, 1998; Brouns et al., 2005), after 8-10 hour fast for each subject. Glucose was used as the reference food $(25.000 \mathrm{~g}$, gskGlaxco
Welcome Ceylon Ltd, Sri Lanka). Test meal of boiled sweet potatoes was given to be consumed within 15 minutes with $250 \mathrm{~mL}$ of water to each volunteer. GI values of ten individuals were averaged to calculate the GI of each variety. Glycaemic load of sweet potato samples were calculated with available digestible carbohydrate content $(\mathrm{g})$ in a serving size and the sample's GI (Venn et al., 2006).

\section{Statistical analysis}

Proximate data are presented as mean \pm SD. Significances were calculated at 95\% confidence interval. The glycaemic index data are presented as mean \pm SEM. The data were analyzed using the statistical software (SPSS) and Microsoft Office Excel 2010.

\section{Ethical clearance}

Ethical clearence for the study was obtained from the Ethical Review Committee of the Faculty of Medical Sciences, University of Sri Jayewardenepura (ERC no: 48/15). Informed written consent was obtained from each volunteer prior to the study and they were informed that they can withdraw from the study at anytime.

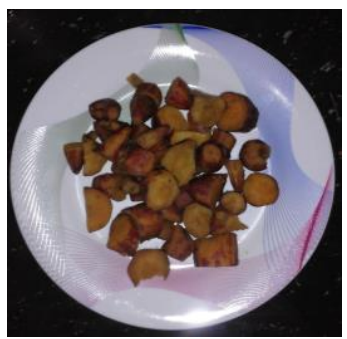

(a)

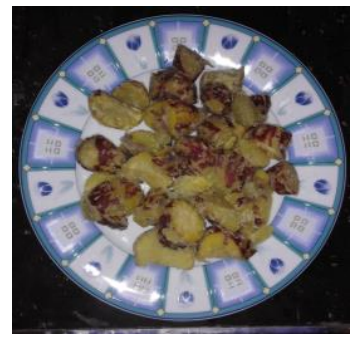

(b)

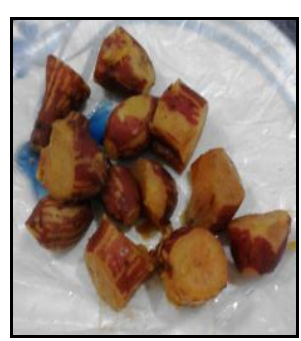

(c)

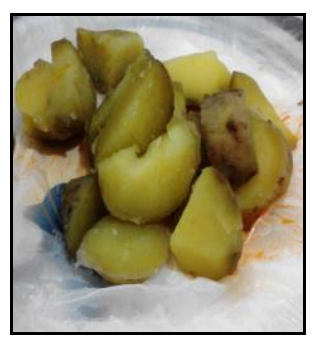

(d)

Figure 1: Sample portion sizes of some sweet potato varieties ((a) Ranabima (b) Wariyapola Red (c) Ama (d) Gannoruwa White). 


\section{RESULTS}

\section{Nutrient composition}

The moisture, ash, crude protein and fat contents, digestible carbohydrate contents determined using enzymatic assay procedure and total dietary fiber contents, including soluble and insoluble dietary fiber of sweet potatoes are presented in Table 1.

The moisture content of boiled sweet potatoes ranged from $71.5 \%-80.6 \%$. The contents of ash, crude protein and crude fat each were less than 6\% (dry weight basis) with the highest $(\mathrm{P} \leq 0.05)$ crude protein found in $M P$ variety. Carbohydrate was the major nutrient present in all the tested sweet potato varieties. Digestible carbohydrate content of sweet potatoes ranged from 29\% $88 \%$ (dry weight, DW) with Makandura Purple variety having the highest $(\mathrm{P} \leq 0.05)$ digestible carbohydrate whereas CARI 273 contained the lowest $(\mathrm{P} \leq 0.05)$. Total dietary fiber content of all the sweet potatoes were above $9.5 \%$ on DW, with higher contribution from insoluble dietary fibers.

\section{Glycaemic index and glycaemic load}

Portion sizes provided for glycaemic index determination, glycaemic indices, and glycaemic loads of selected sweet potato varieties are presented in Table 2. Blood glucose peaked at $30 \mathrm{~min}$ after consuming majority of sweet potatoes and the peaks were lower or similar (123-138 mg/dL) to glucose $(132-143 \mathrm{mg} / \mathrm{dL})$ except for Ranabima variety. All the sweet potato varieties elicited high GI values (86-119) and high glycaemic load values (> 20) for the portion used to determine the GI. Among the varieties studied Ama had a comparatively lower GI (86) followed by $H M$ (89) compared to other varieties.

The GL of the given portion was high (>20) for all the varieties. However, according to the participants the portions given to determine the GI (containing $25 \mathrm{~g}$ of digestible carbohydrate) were too large to be consumed except for $M P$ variety (Table 2 ). When the portion sizes were reduced to actual edible portion sizes, all the varieties had medium or low glycaemic loads except Wariyapola White and Makandura Purple varieties. Thus consumption in moderate quantity would not produce high glycaemic response. 
G. R. N. N. WAIDYARATHNA et al. / Int. J. Biol. Chem. Sci. 15(4): 1410-1420, 2021

Table 1: Moisture, ash, crude protein, fat, digestible carbohydrate, insoluble, soluble and total dietary fiber contents of boiled sweet potato on dry weight (g/100g) basis.

\begin{tabular}{|c|c|c|c|c|c|c|c|c|c|}
\hline \multirow{2}{*}{$\begin{array}{l}\text { Sweet } \\
\text { potato } \\
\text { variety }\end{array}$} & \multicolumn{2}{|l|}{ Moisture \% } & \multirow[t]{2}{*}{ Ash\% } & \multirow{2}{*}{$\begin{array}{l}\text { Crude } \\
\text { protein \% }\end{array}$} & \multirow{2}{*}{$\begin{array}{l}\text { Crude fat } \\
\%\end{array}$} & \multirow{2}{*}{$\begin{array}{l}\text { Digestible } \\
\text { carbohydrate }\end{array}$} & \multicolumn{3}{|c|}{ Dietary fiber (DF)\% } \\
\hline & $\begin{array}{l}\text { Boiled tubers } \\
\text { (fresh weight) }\end{array}$ & Flour & & & & & Insoluble DF & Soluble DF & Total DF \% \\
\hline Ama & $77.2 \pm 1.0^{\mathrm{a}}$ & $5.5 \pm 0.1^{\mathrm{a}}$ & $4.8 \pm 0.3^{\mathrm{a}}$ & $3.0 \pm 0.3^{\mathrm{a}}$ & $2.6 \pm 0.3^{\mathrm{a}}$ & $39.4 \pm 0.6^{\mathrm{a}}$ & $11.1 \pm 0.1^{\mathrm{a}}$ & $3.8 \pm 0.1^{\mathrm{a}, \mathrm{c}}$ & $14.9 \pm 0.1^{\mathrm{a}}$ \\
\hline Dhawala & $72.9 \pm 1.2^{\mathrm{b}}$ & $7.2 \pm 0.2^{b}$ & $3.7 \pm 0.1^{\mathrm{a}, \mathrm{b}}$ & $3.8 \pm 0.1^{\mathrm{b}}$ & $4.7 \pm 0.4^{\mathrm{b}}$ & $47.7 \pm 0.8^{b}$ & $9.1 \pm 0.1^{\mathrm{a}}$ & $0.6 \pm 0.1^{\mathrm{b}}$ & $9.7 \pm 0.1^{b}$ \\
\hline$W W$ & $71.5 \pm 1.6^{b}$ & $5.0 \pm 0.2^{\mathrm{c}}$ & $3.1 \pm 0.1^{\mathrm{b}}$ & $4.5 \pm 0.2^{c}$ & $4.1 \pm 0.2^{\mathrm{b}, \mathrm{c}}$ & $61.8 \pm 0.5^{c}$ & $9.7 \pm 0.1^{\mathrm{a}}$ & $3.6 \pm 0.1^{\mathrm{a}, \mathrm{c}}$ & $13.3 \pm 0.1^{\mathrm{a}, \mathrm{c}}$ \\
\hline$W R$ & $77.5 \pm 1.4^{\mathrm{a}}$ & $7.3 \pm 0.3^{b}$ & $3.5 \pm 0.1^{\mathrm{a}, \mathrm{b}}$ & $3.0 \pm 0.1^{\mathrm{a}}$ & $4.4 \pm 0.5^{b}$ & $34.3 \pm 0.5^{\mathrm{d}}$ & $8.7 \pm 0.1^{b}$ & $2.6 \pm 0.1^{\mathrm{a}}$ & $11.3 \pm 0.1^{\mathrm{c}}$ \\
\hline$H M$ & $74.9 \pm 2.0^{\mathrm{b}}$ & $4.4 \pm 0.1^{\mathrm{c}}$ & $3.7 \pm 0.1^{\mathrm{a}}$ & $3.0 \pm 0.1^{\mathrm{a}}$ & $3.8 \pm 0.2^{\mathrm{b}, \mathrm{c}}$ & $43.8 \pm 0.3^{b}$ & $10.1 \pm 0.1^{\mathrm{a}}$ & $2.5 \pm 0.1^{\mathrm{a}}$ & $12.6 \pm 0.1^{\mathrm{c}}$ \\
\hline CARI 273 & $78.5 \pm 1.5^{\mathrm{a}}$ & $6.0 \pm 0.1^{\mathrm{a}}$ & $4.0 \pm 0.1^{\mathrm{a}}$ & $3.0 \pm 0.1^{\mathrm{a}}$ & $3.6 \pm 0.5^{b, c}$ & $29.0 \pm 0.7^{e}$ & $10.1 \pm 0.1^{\mathrm{a}}$ & $2.9 \pm 0.1^{\mathrm{a}}$ & $13.0 \pm 0.1^{\mathrm{a}, \mathrm{c}}$ \\
\hline Ranabima & $81.3 \pm 1.0^{c}$ & $7.7 \pm 0.1^{\mathrm{b}}$ & $4.2 \pm 0.3^{\mathrm{a}}$ & $3.3 \pm 0.2^{\mathrm{a}}$ & $5.3 \pm 0.4^{\mathrm{b}}$ & $31.4 \pm 0.7^{\mathrm{d}, \mathrm{e}}$ & $10.4 \pm 0.1^{\mathrm{a}}$ & $2.5 \pm 0.1^{\mathrm{a}}$ & $12.9 \pm 0.1^{\mathrm{a}, \mathrm{c}}$ \\
\hline$G W$ & $78.6 \pm 1.5^{\mathrm{a}}$ & $9.8 \pm 0.1^{\mathrm{e}}$ & $5.0 \pm 0.1^{\mathrm{a}}$ & $4.5 \pm 0.2^{\mathrm{c}}$ & $4.5 \pm 0.3^{b}$ & $39.9 \pm 0.6^{\mathrm{a}}$ & $9.0 \pm 0.1^{\mathrm{a}}$ & $9.1 \pm 0.1^{\mathrm{d}}$ & $18.1 \pm 0.1^{\mathrm{c}}$ \\
\hline$M P$ & $72.4 \pm 1.4^{\mathrm{b}}$ & $8.8 \pm 0.2^{\mathrm{f}}$ & $3.3 \pm 0.1^{\mathrm{a}, \mathrm{b}}$ & $5.9 \pm 0.2^{f}$ & $3.8 \pm 0.2^{b, c}$ & $88.4 \pm 0.9^{g}$ & $6.9 \pm 0.1^{\mathrm{c}}$ & $2.7 \pm 0.1^{\mathrm{a}}$ & $9.6 \pm 0.1^{b}$ \\
\hline
\end{tabular}

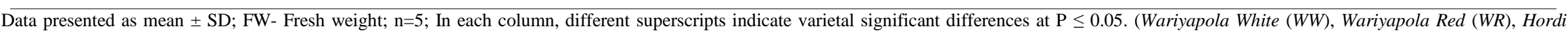
Malee (HM), Gannoruwa White (GW), Makandura Purple (MP)). 
Table 2: Portion sizes given for glycaemic index determination, glycaemic indices, glycaemic load values, average estimated edible portion sizes and glycaemic load values for edible portion sizes of sweet potatoes.

\begin{tabular}{lllllll}
\hline $\begin{array}{l}\text { Variety } \\
\text { name }\end{array}$ & $\begin{array}{l}\text { Portion } \\
\text { size }(\mathbf{g})\end{array}$ & $\begin{array}{l}\text { Glycaemic } \\
\text { index } \\
( \pm \text { SEM) }\end{array}$ & $\begin{array}{l}\text { Glycaemic } \\
\text { load }\end{array}$ & $\begin{array}{l}\text { Edible } \\
\text { proportion from } \\
\text { given portion }\end{array}$ & $\begin{array}{l}\text { Estimated } \\
\text { edible portion } \\
\text { size }(\mathbf{g})\end{array}$ & $\begin{array}{l}\text { Glycaemic } \\
\text { load for edible } \\
\text { portion }\end{array}$ \\
\hline Ama & 287 & $86 \pm 9$ & $22(\mathrm{H})$ & $1 / 2$ & 144 & $11(\mathrm{M})$ \\
Dhawala & 194 & $103 \pm 9$ & $26(\mathrm{H})$ & $3 / 4$ & 146 & $19(\mathrm{M})$ \\
$W W$ & 144 & $119 \pm 7$ & $30(\mathrm{H})$ & $3 / 4$ & 108 & $22(\mathrm{H})$ \\
WR & 324 & $100 \pm 7$ & $25(\mathrm{H})$ & $1 / 2$ & 162 & $13(\mathrm{M})$ \\
HM & 224 & $89 \pm 9$ & $22(\mathrm{H})$ & $1 / 2$ & 112 & $11(\mathrm{M})$ \\
CARI 273 & 407 & $104 \pm 7$ & $26(\mathrm{H})$ & $1 / 4$ & 102 & $7(\mathrm{~L})$ \\
Ranabima & 416 & $119 \pm 6$ & $30(\mathrm{H})$ & $1 / 4$ & 104 & $7(\mathrm{~L})$ \\
GW & 311 & $111 \pm 8$ & $28(\mathrm{H})$ & $1 / 2$ & 156 & $14(\mathrm{M})$ \\
MP & 106 & $104 \pm 9$ & $26(\mathrm{H})$ & 1 & 106 & $26(\mathrm{H})$ \\
\hline
\end{tabular}

$\mathrm{N}=10$; SEM = standard error of the mean; H-high glycaemic load (GL[>20]); M-medium GL [>10-19]; L-low GL [1-10]; (Wariyapola White (WW), Wariyapola Red (WR), Hordi Malee (HM), Gannoruwa White (GW), Makandura Purple (MP)).

\section{DISCUSSION}

Moisture content of boiled varieties comprised more than two third of the weight irrespective of variety. The protein contents of the studied tubers were similar to that of Jamaican varieties while comparatively higher in fat contents (Bahado-Singh et al., 2011). Differently processed sweet potatoes (raw, baked, steamed, and dehydrated sweet potatoes) contained $1.0 \pm 0.7 \%$ fat and $7.6 \pm$ $0.9 \%$ protein (Allen et al., 2012) where the fat content was lower and protein was higher compared to present study. However, compared with boiled manioc (Hettiaratchi et al., 2009; Famurewa et al., 2013), sweet potatoes had higher protein and fat contents thus nutritionally better. Digestible starch contents of Nigerian sweet potato varieties (Afolabi et al., 2016) were within the range of present study results. Considering the dietary fiber contents reported in the present study, comparatively higher total dietary fiber contents $(31 \pm 14 \%)$ were found in raw, baked, steamed, and dehydrated sweet potatoes (Allen et al., 2012). Thus sweet potatoes could be a source of prebiotics which promote the action of probiotics in human gastrointestinal tract since the tubers contain considerable amount of dietay fiber (Park and Floch, 2007).

Based on the GI determination, the decline in blood glucose following peaking was slower for all sweet potato varieties when compared to glucose response (Figure 2) indicating that high blood glucose levels were maintained for an extended period. The rapid peaking may be due the presence of free maltose and rapidly digestible starch in the tubers (unpublished data). The slower decline in blood glucose may be due to slower gastric 
emptying rate contributing to maintain extended exposure to enzymatic digestion releasing glucose to maintain higher blood glucose. This was further confirmed by the response received from the volunteers who said that they were not feeling hungry even after 2 hours. The high insoluble dietary fibre may have contributed to the slower gastric emptying rate. The heat stable alpha and beta amylases in sweet potatoes (Hagenimana et al., 1994) contributing to increase the maltose (Eo et al., 2016) content in boiled sweet potatoes may also contribute to high peak and high GIs. The dietary fiber contribution in boiled tubers thus is not adequate to overcome the effects of above factors to reduce the GI (Monnier et al., 1978).

Glycaemic index of boiled potatoes from different countries ranged between 56 to 118 against glucose (Atkinson et al., 2008). The estimated in vitro glycaemic index (GI) value of sweet potato was $62.37 \%$ (Afolabi et al., 2016). The GI of boiled Jamaican sweet potatoes were $41 \pm 5-50 \pm 3$ and comparatively lower than the GI reported for other different cooking methods such as frying $(63 \pm 2-77 \pm 4)$, baking (82 $\pm 3-94 \pm 3)$ and roasting (79 $\pm 4-$ 93 \pm 2 ) (Bahado-Singh et al., 2011). In the above study the portion sizes for the GI determination had been calculated based on the available carbohydrate contents (calculated by difference) and for boiled samples portion sizes were reported as $218 \mathrm{~g}$ - $346 \mathrm{~g}$ (50 g available carbohydrate portion) (Bahado-Singh et al., 2011). The portions of the present study in comparison to other studies were large as the digestible carbohydrate contents were lower than carbohydrate contents reported in many studies which were calculated by difference, except for MP variety (Bahado-Singh et al., 2011; Ellong et al., 2014; Afolabi et al., 2016) and the high amount of moisture (72- $81 \%$ ) in boiled tubers.

Although there were no published data on GI of Sri Lankan sweet potato varieties, when compared with some reported data on sweet potatoes from different countries (Foster-Powell et al., 2002; Atkinson et al.,
2008; Bahado-Singh et al., 2011), comparatively higher GI values were observed. This could be due to overestimation of available carbohydrate content in all above studies as it was calculated by difference. The overestimation of available carbohydrates will inevitably lead to an underestimation of portion sizes eliciting lower glycaemic response and GIs. In addition, the agroclimatic differences and varietal differences may also contribute the nutrients present in the tubers (Ukom et al., 2009).

The high GI values which indicate high digestibility and maximum glucose release to blood stream and maintenance of high levels for an extended period makes these sweet potatoes ideal for consumption by individuals such as athletes who are recommended to consume high glycaemic index foods during period of exercise to ensure rapid digestion and absorption, leading to elevated blood glucose levels during exercise. Post exercise meals should also consist of high glycaemic index carbohydrate foods as low glycaemic foods do not induce adequate muscle glycogen re-synthesis compared with high glycaemic index foods (Walton and Rhodes, 1997). Similarly high GI energy dense foods which are easily digested are beneficial to fulfill the energy and nutritional requirement of the malnourished individuals, including elderly (Fatima and Khan, 2015) and growing children who have lower food intakes, as high GI foods are more palatable (Warren et al., 2003). Therefore, incorporation of boiled sweet potato in the meals or using flour in producing food for children, elderly and athletes who require energy dense foods with added provision of vitamins, minerals, fibers and antioxidants can be highly recommended. For others who desire to consume any variety of sweet potato, a low GL portion can be calculated using the data (GI and available carbohydrate) obtained in the present study. This data thus will also be useful to nutritionists and dieticians. 


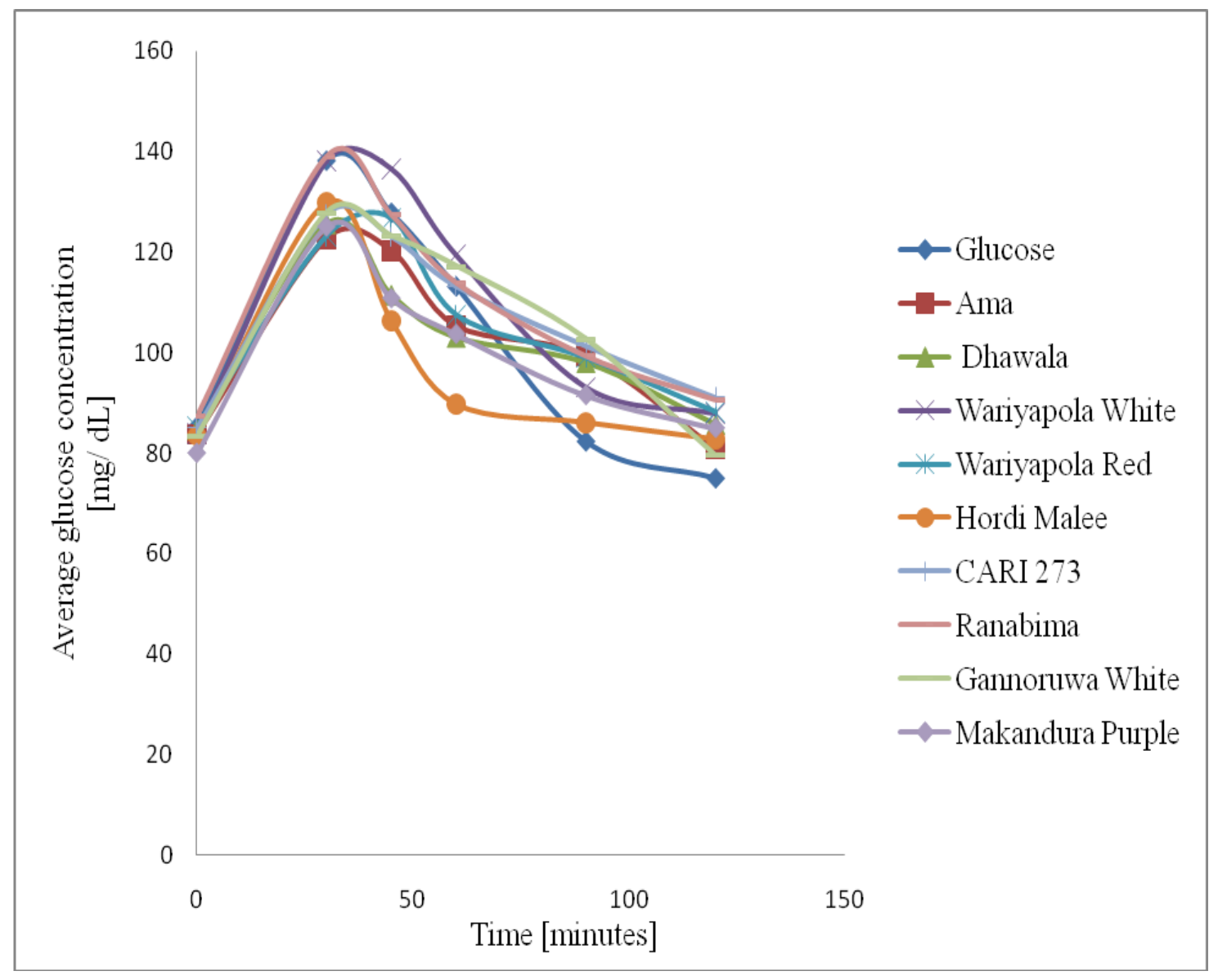

Figure 2: Glycaemic curves of sweet potato varieties and standard glucose.

\section{Conclusion}

Sweet potatoes are a good source of highly available carbohydrate thus energy with considerable amount of dietary fiber than any other nutrient. Glycaemic indices of all studied sweet potatoes were high providing high glycaemic loads. However, when considering actual edible portion sizes, the GL of majority of the varieties elicit medium or low glycaemic load values due to high moisture in boiled tubers which contributes to larger portion sizes thus limiting the carbohydrate intake. Sweet potatoes are suitable for individuals who require high energy food and have the protential to be included in high energy food products.

\section{AUTHORS' CONTRIBUTIONS}

GRNNW carried out the experimental work, acquired the data \& analysed and drafted the preliminary manuscript; SE designed the study, directed and supervised experimental work \& data analyses, and finalised the manuscript. AC provided scholarly input during the process.

\section{COMPETING INTERESTS}

The authors declare that they have no competing interests.

\section{ACKNOWLEDGEMENTS}

The authors gratefully acknowledge the University of Sri Jayewardenepura [grant 
number ASP/01/RE/MED/2015/48] for the financial support, the volunteers who participated in the GI study, Plant Genetic Resource Centre, Gannoruwa and Agricultural Research Centre, Makandura, for providing sweet potatoes. The authors also acknowledge Ms Ganeshika Amarathunga for the technical assistance provided during the study.

\section{REFERENCES}

Afolabi OA, Osamudiamen PM, Osundahunsi OF. 2012. Chemical Properties, in vitro Starch Digestibility and the Estimated Glycemic Index of Water Yam, Cocoyam, Sweet Potato and Cassava. Applied Tropical Agriculture., 21(3): 19-26.

Allen JC, Corbitt AD, Maloney KP, Butt MS, Truong V. 2012. Glycemic Index of Sweet Potato as Affected by Cooking Methods. The Open Nutrition Journal, 6 : 1-11.

DOI: $10.2174 / 1874288201206010001$

AOAC. 1984. Official Methods of Analysis $\left(14^{\text {th }}\right.$ edn). Association of Official Analytical Chemists: Washington DC.

AOAC. 2000. Official Methods of Analysis

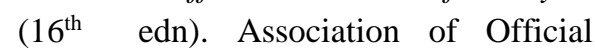
Analytical Chemists: Arlington (VA).

AOAC. 2005. Official Methods of Analysis $\left(18^{\text {th }}\right.$ edn). Association of Official Analytical Chemists: Gaithersburg MD.

Atkinson FS, Foster-Powell K, Brand-Miller JC. 2008. International Tables of Glycemic Index and Glycemic Load Values: 2008. Diabetes Care, 31(12): 2281-2283. DOI: $10.2337 / \mathrm{dc} 08-1239$

Bahado-Singh PS, Riley CK, Wheatley AO, Lowe HIC. 2011. Relationship between processing method and the glycemic indices of ten sweet potato (Ipomoea batatas) cultivars commonly consumed in Jamaica. Journal of Nutrition and Metabolism, 2011: 1-6. DOI: https://doi.org/10.1155/2011/584832

Brouns F, Bjorck I, Frayn KN, Gibbs AL,
Lang V, Slama G, Wolever TMS. 2005. Glycaemic index methodology. Nutrition Research Reviews., 18(1): 145. DOI: 10.1079/NRR2005100

Chandrasekara A, Kumar TJ. 2016. Roots and tuber crops as functional foods: A review on phytochemical constituents and their potential health benefits. International Journal of Food Science, 2016: 1-15. DOI:

https://doi.org/10.1155/2016/3631647

Croon L, Guchs G. 1980. Fatthaltsbestamning I mjol och mjolprodketer (Crude fat analysis of different flours and flour products). Var Foda, 32: 425-427.

Djinet AI, Nana R, Tamini Z, Badiel B. 2014. Mise en évidence des valeurs nutritionnelles de dix (10) variétés de patate douce [Ipomea batatas (L.) Lam.] du Burkina Faso (Highlighting nutritional value of ten (10) varieties of sweet potato (Ipomoea batatas (L.) Lam.) of Burkina Faso). International Journal of Biological and Chemical Sciences, 8(5): 2062-2070. DOI: http://dx.doi.org/10.4314/ijbcs.v8i5.12

Doussoh AM, Dangou JS, Houedjissin SS, Assogba AK, Ahanhanzo C. 2016. Analyse des connaissances endogènes et des déterminants de la production de la patate douce [Ipomoea batatas (L.)], une culture à haute valeur socioculturelle et économique au Bénin (Analysis of endogenous knowledge and determinants of sweet potato production [Ipomoea batatas (L.)], a high socio-cultural and economic value culture in Benin). International Journal of Biological and Chemical Sciences, 10(6): 2596-2616. DOI:

http://dx.doi.org/10.4314/ijbcs.v10i6.16

Ellong EN, Billard C, Adenet S. 2014. Comparison of Physicochemical, Organoleptic and Nutritional Abilities of Eight Sweet Potato (Ipomoea batatas) Varieties. Food and Nutrition Sciences., 
5:

196-211.

DOI: https://doi.org/10.4236/fns.2014.52025

Eo M, Ibok O, Wo E, Ee C. 2016. Thermal Stability of $\beta$-Amylase Activity and Sugar Profile of Sweet- Potato Varieties during Processing. Journal of Nutrition \& Food Sciences, 6(4): 1-5. DOI: 10.4172/2155-9600.1000515

Famurewa JAV, Oluwamukomi MO, Alaba Jo. 2013. Effect of different drying methods on the physicochemical characteristics of cassava flour ("pupuru"). International Journal of Biological and Chemical Sciences, 7(2): 832-839.

DOI: http://dx.doi.org/10.4314/ijbcs.v7i2.38

FAO (Food and Agriculture Organization) of the United Nations. 2016. Food and agricultural data, Sweet potatoes, Crops (production). Retrieved on November 30, 2018 from wesite: http://www.fao.org/faostat/en/\#search/S weet potatoes.

FAO/WHO. 1998. Carbohydrates in human nutrition : report of a joint $\mathrm{FAO} / \mathrm{WHO}$ expert consultation. Food and Nutrition paper 66. Food and Agriculture Organization. Rome.

FAOSTAT. 2017. Food Balanced Sheet. Food and Agriculture Organization of the United Nations (FAOSTAT). 2017. [cited Retrieved on October 31, 2019 from wesite: http://www.fao.org/faostat/en/\#data/QC/ visualize.

Fatima S, Khan SA. 2015. Nutritional Supplements And Their Use In The Treatment Of Review Article Nutritional Supplements And Their Use In The Treatment. J Ayub Med Coll Abbottabad, 27(4): 911-922.

Foster-Powell K, Holt SH, Brand-Miller JC. 2002. International table of glycemic index and glycemic load values: 2002. The American Journal of Clinical Nutrition, $\quad$ 76(1): $\quad 5-56 . \quad$ DOI: 10.1093/ajcn/76.1.5

Hagenimana V, Vlblna L, Simard E. 1994. Sweetpotato $\alpha-$ and $\beta$-Amylases : Characterization Kinetic Studies with Endogenous Inhibitors. Journal of Food Science, 59(2): 373-377. DOI: https://doi.org/10.1111/j.1365-

2621.1994.tb06970.x

Hettiaratchi UPK, Ekanayake S, Welihinda J. 2009. Do Sri Lankan meals help decrease blood glucose response? Ceylon Medical Journal, 54(2): 39 . DOI: 10.4038/cmj.v54i2.793

Kamal MS, Islam MN, Aziz MG. 2013. Effect of sweet potato flour of two local varieties on quality of breads. Journal of the Bangladesh Agricultural University, 11(2): 301-306. DOI: http://dx.doi.org/10.3329/jbau.v11i2.199 29

Monnier L, Pham TC, Aguirre L, Orsetti A, Mirouze J. 1978. Influence of indigestible fibers on glucose tolerance. Diabetes Care, 1(2): 83-88. DOI: 10.2337/diacare.1.2.83

Mussoline WA, Wilkie AC. 2017. Feed and fuel: the dual-purpose advantage of an industrial sweetpotato. Journal of the Science of Food and Agriculture, 97(5): 1567-1575.

DOI: https://doi.org/10.1002/jsfa.7902

Oluwalana IB, Malomo SA, Ogbodogbo EO. 2012. Quality assessment of flour and bread from sweet potato wheat composite flour blends. International Journal of Biological and Chemical Sciences, 6(1): 65-76. DOI: http://dx.doi.org/10.4314/ijbcs.v6i1.6

Park J, Floch MH. 2007. Prebiotics, Probiotics, and Dietary Fiber in Gastrointestinal Disease. Gastroenterology Clinics of North America, 36(1): 47-63. DOI: https://doi.org/10.1016/j.gtc.2007.03.001

Rose I, Vasanthakaalam H. 2011. Comparison of the Nutrient composition of four 
sweet potato varieties cultivated in Rwanda. American Journal of Food and Nutrition, 1(1): 34-38. DOI: https://doi.org/10.5251/ajfn.2011.1.1.34. 38

Senanayake SA, Ranaweera KKDS, Gunaratne A, Bamunuarachchi A. 2013. Comparative analysis of nutritional quality of five different cultivars of sweet potatoes ( Ipomea batatas (L) Lam) in Sri Lanka. Food Science \& Nutrition, 1(4): 284-291. DOI: https://doi.org/10.1002/fsn3.38

Ukom AN, Ojimelukwe PC, Okpara DA. 2009. Nutrient composition of selected sweet potato [Ipomea batatas (L) Lam] varieties as influenced by different levels of nitrogen fertilizer application. Pakistan Journal of Nutrition, 8(11): 1791-1795.

DOI: 10.3923/pjn.2009.1791.1795

Venn BJ, Wallace AJ, Monro JA, Perry T, Brown R, Frampton C, Green TJ. 2006.
The glycemic load estimated from the glycemic index does not differ greatly from that measured using a standard curve in healthy volunteers. The Journal of Nutrition, 136(5): 1377-1381. DOI: 10.3109/13645706.2012.743919

Walton P, Rhodes EC. 1997. Glycaemic index and optimal performance. Sports Medicine, 23(3): 164-172. DOI: 10.2165/00007256-199723030-00003

Wang A, Li R, Ren L, Gao X, Zhang Y, Ma Z, Ma D, Luo Y. 2018. A comparative metabolomics study of flavonoids in sweet potato with different flesh colors ( Ipomoea batatas (L.) Lam). Food Chemistry, 260: 124-134. DOI: https://doi.org/10.1016/j.foodchem.2018. 03.125

Warren JM, Henry CJK, Simonite V. 2003. Low Glycemic Index Breakfasts and Reduced Food Intake in Preadolescent Children. Pediatrics, 112(5): e414-e414. DOI: 10.1542/peds.112.5.e414. 